\title{
Paideusis
}

\section{Education Lost: Reflections on Contemporary Pedagogical Practice (David Solway)}

\section{William Hare}

Volume 5, Number 2, 1992

URI: https://id.erudit.org/iderudit/1073351ar

DOI: https://doi.org/10.7202/1073351ar

See table of contents

Publisher(s)

Canadian Philosophy of Education Society

ISSN

0838-4517 (print)

1916-0348 (digital)

Explore this journal

Cite this review

Hare, W. (1992). Review of [Education Lost: Reflections on Contemporary Pedagogical Practice (David Solway)]. Paideusis, 5(2), 44-45.

https://doi.org/10.7202/1073351ar

This document is protected by copyright law. Use of the services of Erudit (including reproduction) is subject to its terms and conditions, which can be viewed online.

https://apropos.erudit.org/en/users/policy-on-use/
This article is disseminated and preserved by Érudit.

Érudit is a non-profit inter-university consortium of the Université de Montréal, Université Laval, and the Université du Québec à Montréal. Its mission is to promote and disseminate research.

https://www.erudit.org/en/ 


\section{Book Reviews}

\section{David Solway, Education Lost: Reflections on Contemporary Pedagogical Practice (Toronto: OISE Press, 1989)}

The Foreword to this book would suggest that it was completed in 1985 , but only published in 1989. It remains, however, a timely and trenchant criticism of contemporary education, and teachers and student teachers would do well to face up to Solway's arguments. I read it when it first appeared and have been a little surprised and disappointed that it has not received the kind of attention it deserves. This second reading only confirms the favourable impression formed earlier. Not that it is easy reading. Solway's vocabulary will be found to contain something to defeat almost everyone, and it is amusing to hear Solway himself describe another author's terminology as intimidating! But if the language is challenging, it should also be said at once that there is style, wit, and honesty in these pages, together with many memorable examples and incidents, usually so powerful that explanatory comment from the author would be superfluous. My own favourite is the case of the distinguished poet and critic whose eloquent address to the undergraduates was summed up by one as "a crucification."

Solway's title is also his thesis, namely, that education itself has been lost in the pursuit of techniques, skills, data, how-to manuals, and all the rest of the technical and technological paraphernalia of contemporary pedagogy. There is an echo here of Bertrand Russell's concem earlier in the century about the emergence of a mechanistic outlook, the tendency to uniformity, the suppression of judgment, and so on. The language we use to speak of our activities as teachers now reflects and reinforces this bias, as our metaphors succeed in putting our critical faculties on hold. (Readers of this journal might be interested in comparing Scheffler's comments on the impact of computer language in his recent book In Praise of the Cognitive Emotions.) In short, Solway argues, we have lost sight of what is fundamental and central to education. We have lost whatever hold we once had on the distinction between education and training. Solway has no neat "analysis" to offer us, and a distinction of this sort is not about to be captured in a succinct set of conditions. But in numerous ways throughout the book, he is concerned to remind us of the difference between storing and reproducing skills, and having one's outlook, attitudes, and awareness transformed.

The thesis is brought home in a chapter on "the good teacher" where Solway recalls five of his own teachers who, in very different ways, had a powerful impact on his development. Solway is surely right to insist, as I believe the Keegstra affair confirms, that we have all but lost track of what teaching and good teaching really involve. We have become increasingly preoccupied with "classroom tinkering," as Solway puts it, and reducing teaching to a set of rehearsable routines which can be formulated in quasi-scientific generalizations in a pedagogical manual. A superficial application of fashionable views on "good teaching" would not lead to any of Solway's teachers being so identified. The elementary school teacher, for example, who gave young Solway a severe dressing-down for being thoroughly lazy would not score well under "Gives positive reinforcement." None of these memorable characters would emerge as excellent under conventional generalizations. Sol- 
way, however, is anxious that we look behind and beyond the twaddle to ask what these teachers had to offer, and why he still remembers them. In addition to mastery of their material, they had personality, authenticity, individuality, enthusiasm. And, Solway adds, they expected to be surpassed, not merely equalled, by their students.

None of the teachers who serve as exemplars had been trained to teach. All had a strong academic background and taught at a time, or in a context, where further professional certification was not required. Solway advances for the reader's consideration the new maxim: Teachers cannot be trained, they must be found. A slogan, perhaps, and not to be taken quite literally. Solway, after all, knows that mastery of a subject does not entail competence in its dissemination. Moreover, it becomes clear that his chief concern is with the exaggerated emphasis placed on technical competence at the expense of subject knowledge, leading to a situation where, as he remarks, a new breed of technical experts is forced to scurry over those parts of their subject which they have not mastered. The basic truth, however, in the maxim is that there are qualities involved in being a good teacher which are not readily trained, and in this sense teachers do have to be found. And so far is Solway's general point from the conventional wisdom that if we did find an outstanding teacher, one who lacked professional qualifications for school teaching, we would insist on training anyway.

Solway drags out into the open certain important aspects of teaching about which contemporary experts have been silent, perhaps because superficially they seem to threaten prevalent watchwords like dialogue, openness, and equality. Once exposed, however, it is not easy in good conscience to sweep them aside. For example, Solway reminds us of that Socratic element in good teaching, confronting the learner with his or her ignorance and arrogance. The manuals steer well clear of this; it smacks of authoritarianism. Are we, however, simply to gloss over the possibility that the open expression of opinion is no more than the open expression of nonsense? Solway establishes the general point behind such examples in an important footnote where he observes that particular traits are not necessarily virtues. For the latter, they require a context and a set of conditions, in the absence of which we find "a passion for freedom without content and spontaneity without its informing discipline." We need to ask if the classroom has achieved the conditions where the watchwords make sense.

This is not a book to be readily paraphrased or reduced to a number of points. Its power and value lie in the way in which the author comes at the same theme from many different directions in language and image calculated to provoke us into thought. Philosophers of education will recognize some familiar distinctions and points here, but they have rarely been presented with such passion and conviction. Solway, like his own teachers, has personality, authenticity, and a distinctive voice. He anticipates that some readers will find his tone irritating, and he frankly admits that he has been blunt and personal. In my own view, the style underlines the important point that the voice of inner conviction is too often silent in the all too neutral tones of the classroom. It is a stimulating encounter. 